\title{
A Review of Thermoplastic Composites for Bipolar Plate Materials in PEM Fuel Cells
}

\author{
Rungsima Yeetsorn ${ }^{1}$, Michael W. Fowler ${ }^{2}$ and Costas Tzoganakis ${ }^{2}$ \\ King Mongkut's University of Technology North Bangkok \\ University of Waterloo \\ 1Thailand \\ ${ }^{2}$ Canada
}

\section{Introduction}

Polymer composite materials have particular properties that meet special requirements. A conductive polymer composite is positioned to play an increasingly significant role in industry and academia, specifically in the area of electrical conductivity. Even general knowledge about electrically conductive composites has been available for many years, less attention has been given in the literature to the use of conductive composites for alternative energy production.

Why is the use of composite materials for energy production interesting? With a continued growth in the worldwide demand for energy, there is increasing interest in alternative technologies of energy generation such as fuel cells, for various stationary and mobile applications. In this chapter, the authors are mainly interested in a fuel cell as an energy generator, since a fuel cell is expected to play a major role in the economy of this century and for the foreseeable future. A number of factors provide the incentive for fuel cells to play a role in future energy supplies and for transportations, including climate change, oil dependency and energy security, urban air quality, and growth in distributed power generation [1].

A polymer electrolyte membrane fuel cell (PEMFC) is a good contender for portable and automotive propulsion applications because it provides high power density, solid state construction, high chemical-to-electrical energy conversion efficiency, near zero environmental emissions, low temperature operation $\left(60-120{ }^{\circ} \mathrm{C}\right)$, and fast and easy startup [2,3, and 4]. The U.S. Department of Energy (DOE) has also identified the polymer electrolyte membrane fuel cells as the main candidate to replace the internal combustion engine in transportation applications [2]; however, barriers to commercialization remain. Fundamental technical challenges facing the commercialization of PEM fuel cells are manufacturing and material costs; material durability and reliability; and hydrogen storage and distribution issues $[4,5$, and 6$]$. One of the major factors limiting fuel cell commercialization is the development of bipolar plates, which are one of PEMFC's key components. Bipolar plate characteristic requirements are a challenge for any class of materials, and none fits the profile characteristics exactly. Therefore, research on materials, designs and fabrications of bipolar plates for PEMFC applications is a vital issue for scientists and engineers wanting to achieve the appropriate PEMFC for global commercialization. Several types of materials are 
currently used in bipolar plates, including non-porous graphite plates, metallic plates with or without coating and a number of composite plates. Thermoplastic composite bipolar plates are an attractive option for PEMFC use. They do not only offer advantages of low cost, lower weight and greater ease of manufacturing than traditional graphite, but their properties can also be tailored through changes of reinforcements and the resin systems. The weakest point of thermoplastic composite bipolar plates is their low electrical conductivity compared to conventional graphite or metallic bipolar plates. To increase the electrical conductivity of the plates, electrically conductive polymers or fillers have been used as bipolar plate materials.

This chapter, based on, reviews and extends existing polymer composite material (focusing on thermoplastic composites) and manufacturing literature within the context of a bipolar plate material for a PEMFC application. Throughout this chapter the authors also critique and broaden composite types and alternative manufactures based on functions of bipolar plates and the applications of process selection techniques with respect to a marketable thermoplastic bipolar plate production. Beside an electrically conductive application, the chapter documents interesting information for the design of conducting composite formulations in other applications such as thermal conductivity and mechanical applications. It also permits evaluation and comparison of processing characteristics of different composites, fundamental phenomena for the composite fabrication.

\section{Background of a PEMFC and bipolar plates}

The successful conversion of chemical energy into electrical energy in a primitive fuel cell was first demonstrated over 160 years ago by lawyer and scientist Sir William Grove in 1843[2,4]. These early devices, however, had very low current density. General Electric (GE), a more efficient design in the late 1950s for NASA's Gemini and Apollo space missions, and in addition fuel cell system provided electricity and drinking water for the crew. In developing its fuel cell technology, NASA funded more than 200 research contracts that finally brought the technology to a level that was viable for commercial applications [2, 4]. The types of fuel cells under active development include hydrogen fuelled ones such as alkaline fuel cell (AFC), polymer-electrolyte-membrane fuel cell (PEMFC) and phosphoric-acid fuel cell (PAFC) [7]. The first development of PEMFC was by GE for the Gemini space project, but after that, the PEMFC development became dormant. The improvement of PEMFC programs was reactivated in the 1980s, by Ballard Power Systems, subsequently recognized as the world leader in fuel cell technology [2]. The company and spin-off company Automotive Fuel Cell Corporation (AFCC) has dominated the developing automotive market and has started productions of stationary and portable power applications. For example, the largest fleet of hydrogen fuel cell buses in service was in Whistler, BC, Canada for the 2010 Olympic and Paralympic Winter Games. The twenty transit buses, powered by Ballard's FCvelocity-HD6 power module, provide a $62 \%$ reduction in greenhouse gas emissions compared to diesel buses [8]. There are now many companies, for instance General Motors, Toyota, and Honda, involved in the growth of the PEMFC technology, especially in the automotive fuel cell market. Siemens and some Japanese companies have particularly focused on portable and residential fuel cell systems, where potentially high-volume markets are expected. Companies such as Plug Power and Hydrogenics have made significant advances in the lift truck and back-up power market with their low pressure PEMFC technology. 


\subsection{The operation of a PEMFC ${ }^{[2,4, \text { and } 9]}$}

An expanded view of PEMFC components is shown in Figure 1 below. Key components include the membrane-electrode assembly (MEA), bipolar plates (flow fields or separators), and seals. The traditional PEMFC has a polymer electrolyte membrane placed between two gas diffusion electrodes, an anode and a cathode respectively, each usually containing a metal catalyst, such as $\mathrm{Pt}$, supported by an electrically conductive material. The gas diffusion electrodes are exposed to the respective reactant gases: the reduction gas (hydrogen) and the oxidant gas (oxygen/air). An electrochemical reaction occurs at each of the two junctions (three phase boundaries) where one of the electrodes, the electrolyte polymer membrane and the reactant gas interface.

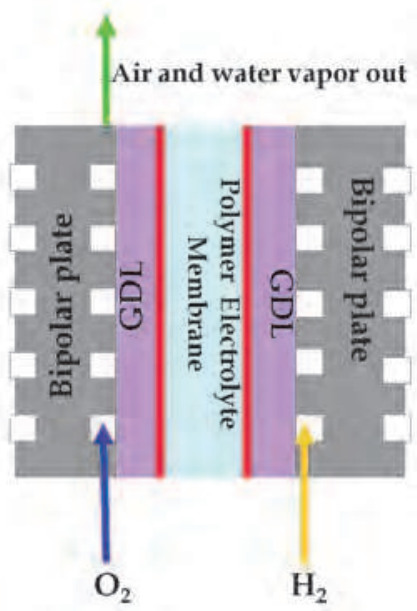

Fig. 1. Exploded view of PEMFC components

The fuel cell is an electrochemical energy device that converts chemical energy, from typically hydrogen, directly into electrical energy. The electrochemical reactions in fuel cells happen simultaneously on both sides of a membrane: the anode and the cathode. The basic PEMFC reactions are shown as follows.

At the anode,

At the cathode,

$$
\mathrm{H}_{2} \longrightarrow 2 \mathrm{H}^{+}+2 \mathrm{e}^{-}
$$

Overall,

$$
1 / 2 \mathrm{O}_{2}+2 \mathrm{H}^{+}+2 \mathrm{e}^{-} \longrightarrow \mathrm{H}_{2} \mathrm{O}+286 \mathrm{~kJ} / \mathrm{mol}
$$

$$
\mathrm{H}_{2}+1 / 2 \mathrm{O}_{2} \longrightarrow \mathrm{H}_{2} \mathrm{O}+286 \mathrm{~kJ} / \mathrm{mol}
$$

Figure 2 shows a schematic of a PEMFC operation to gain a fundamental understanding of the polymer electrolyte membrane fuel cell technology. During PEMFC operations, hydrogen permeates through the anode and interacts with the noble metal catalyst, producing electrons and protons (1). The electrons are conducted via an electrically conductive material through an external circuit to the cathode, while the protons are simultaneously transferred via an ionic route through a polymer electrolyte membrane to the cathode. This polymer membrane also serves as a gas barrier so that the reactant species 
cannot freely combine. At the cathode, oxygen permeates to the catalyst sites where it reacts with the protons and electrons when properly hydrated, producing the reaction (2). Consequently, the products of the PEMFC reactions are water, electricity and heat.

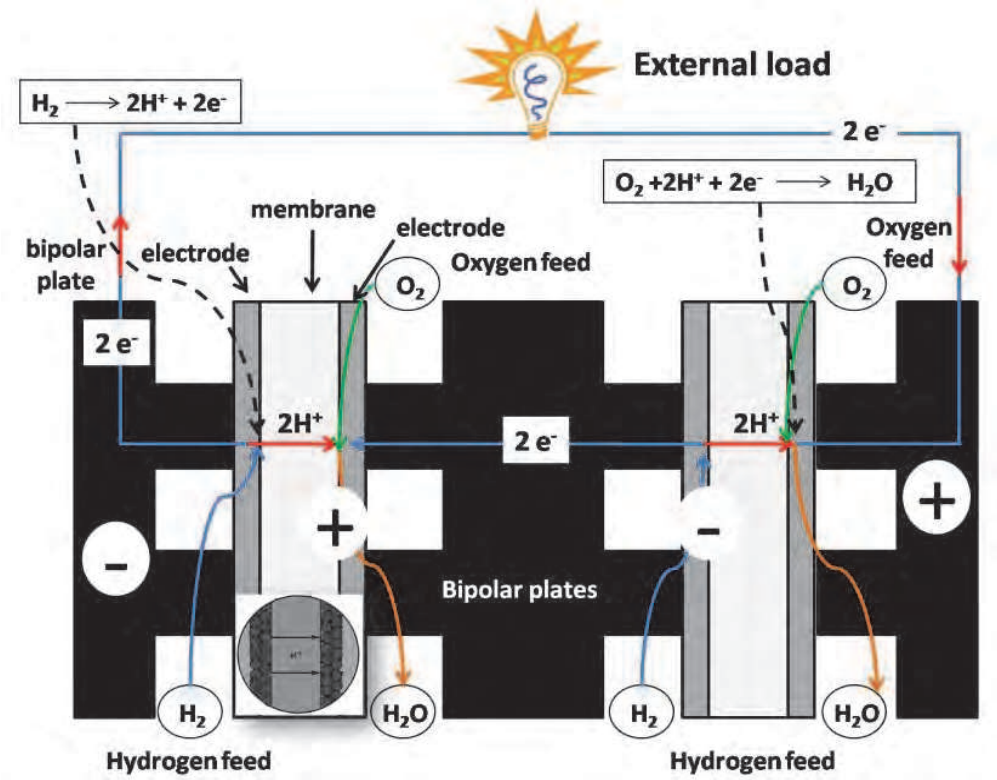

Fig. 2. Schematic of PEMFC operation [2]

\subsection{Bipolar plates ${ }^{[2,4 \text {, and } 9]}$}

The bipolar plate performs a number of functions within the PEMFC as described below.

1. Conducting electrons to complete the circuit, including by collecting and transporting electrons from the anode and cathode, as well as, connecting individual fuel cells in series to form a fuel cell stack of the required voltage (i.e., fuel cells are typically arranged in a bipolar configuration);

2. Providing a flow path for gas transport to distribute the gases over the entire electrode area uniformly;

3. Separating oxidant and fuel gases and feeding $\mathrm{H}_{2}$ to the anode and $\mathrm{O}_{2}$ to the cathode, while removing product water and un-reacted gases;

4. Providing mechanical strength and rigidity to support the thin membrane and electrodes and clamping forces for the stack assembly;

5. Providing thermal conduction to help regulate fuel cell temperature and removing heat from the electrode to the cooling channels.

The materials of the bipolar plate must have particular properties because of its multiple responsibilities and the challenging environment in which the fuel cell operates. Material's properties must be considered for achievable design for a fuel cell application, specifically, electrical and thermal conductivity, gas permeability, mechanical strength, corrosion resistance and low weight. An ideal material should combine the following characteristics that are defined by Department of Energy (DOE) as shown in table 1. 


\begin{tabular}{|c|c|}
\hline Property & Value \\
\hline Electrical conductivity & $>100 \mathrm{Scm}^{-1}$ \\
\hline Contact resistance & $0.1-0.2 \mathrm{ohmcm}^{2}$ \\
\hline Thermal conductivity & $>10 \mathrm{~W}(\mathrm{mK})^{-1}$ \\
\hline Weight & $<0.4 \mathrm{kgkW}^{-1}$ \\
\hline Flexural strength & $\geq 25 \mathrm{MPa}$ \\
\hline Flexibility & $3-5 \%$ deflection at mid-spa \\
\hline Compression strength & $>50 \mathrm{MPa}$ \\
\hline Tensile strength & $\geq 41 \mathrm{MPa}$ \\
\hline Gas permeability & $<2 \times 10^{-6} \mathrm{~cm}^{3} \mathrm{~s}^{-1} \mathrm{~cm}^{-2}$ \\
\hline Cost & $\$ 25 / \mathrm{kW}$ or $<\$ 10 /$ plate. \\
\hline Corrosion resistance & $<1 \mu \mathrm{A} \mathrm{cm}^{-2}$ \\
\hline
\end{tabular}

Table 1. US DOE technical targets for composite bipolar plates [10,11]

Currently, efforts to improve the PEMFC cost and reliability for the industry, including the automotive industry, are comprised of reducing the cost and weight of the fuel cell stack, the goal being a $50 \mathrm{~kW}$ system of $\$ 35 / \mathrm{kW}$ and $<133 \mathrm{~kg}$ in mass [12].The bipolar plates in the stack require significant improvement, since bipolar plates account for approximately $55 \%$ of the PEMFC weight, and $37 \%$ of the stack manufacturing and materials cost $[13,14]$ as shown in Figure 3. Accordingly, the development of bipolar plates may present opportunities for cost and weight reductions in PEMFCs. Moreover, bipolar plate characteristic requirements are a challenge for any class of materials, and none fits the profile characteristics exactly. Therefore, research on materials, designs and fabrications of bipolar plates for PEMFC applications is a vital issue for scientists and engineers wanting to achieve the appropriate PEMFC for global commercialization.

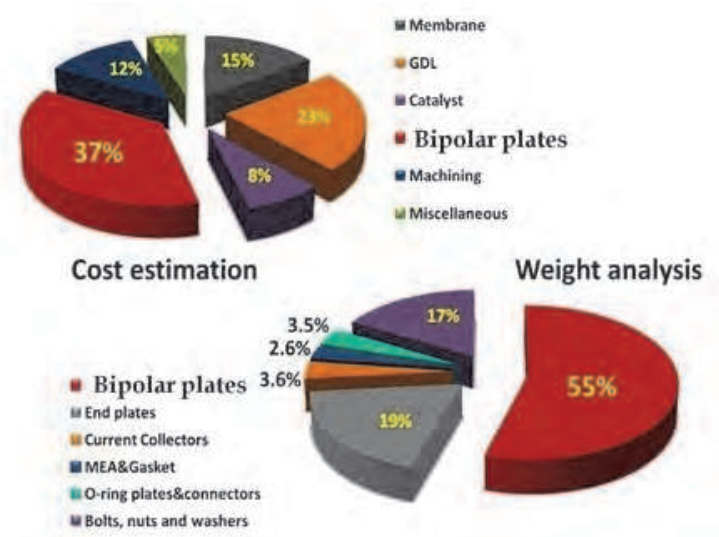

Fig. 3. Relative cost and weight components from a PEMFC using graphite bipolar plate [11]

\section{Bipolar plate materials}

Several types of materials are currently used in bipolar plates, including non-porous graphite plates, metallic plates with or without coating and a number of composite plates. 


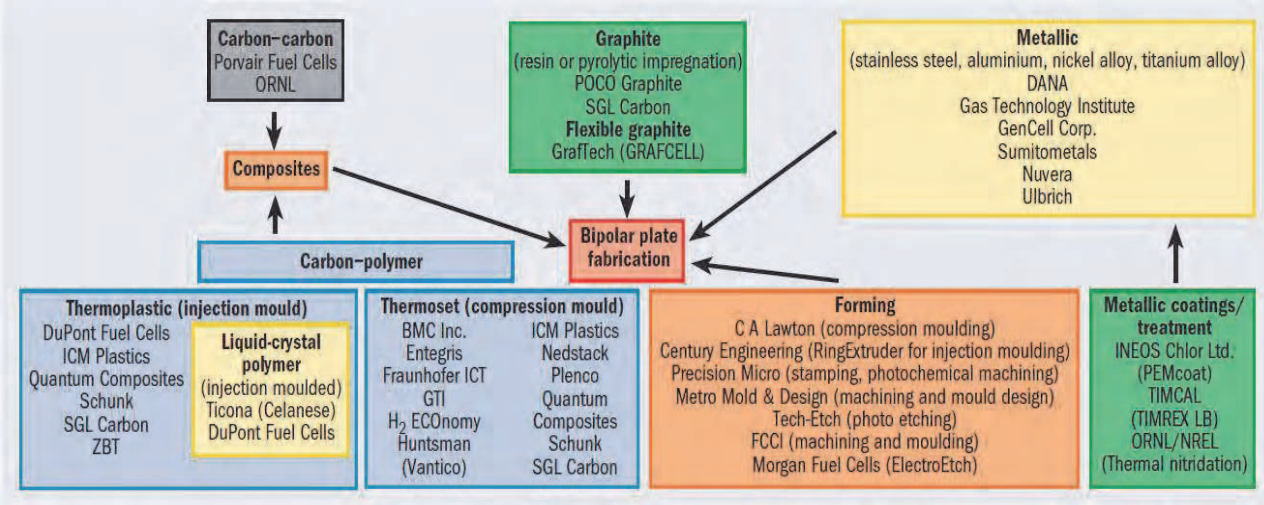

Fig. 4. Bipolar plate materials and names of manufacturers [3]

\subsection{Metallic bipolar plates ${ }^{[15,16, \text { and } 17]}$}

Metals, as sheets, are potential candidates for bipolar plate material since they have good mechanical stability, electrical and thermal conductivity and gas impermeability. Probably the most important benefit is that the resultant stack can be smaller and lighter than graphite bipolar plates. Two advantages to metallic plates that they can be stamped to accommodate flow channels and that the resultant plate can be varied thick, for example 100 $\mu \mathrm{m}$. However, the main disadvantage of metal plates is their susceptibility to corrosion and dissolution in the fuel cell operating environment of $80{ }^{\circ} \mathrm{C}$ and a $\mathrm{pH}$ of $2-3$. This corrosion is harmful to fuel cell performance for the following reasons [18]. First, surface oxide creation significantly enlarges the contact resistance between the plate and the GDL. Second, the corrosion process changes the morphology of the surface, potentially reducing the contact area with the GDLs. Lastly, when the metal plate is dissolved, and the dissolved metal ions diffuse into the PEM membrane and become trapped in the ion exchange sites [19].This trapping results in ionic conductivity diminution, leading to increased membrane degradation. To solve these issues, researchers have considered of non-coated metal alloys, precious non-coated metals, and coated metals with a protective layer.

\subsection{Graphite bipolar plates ${ }^{[15,16]}$}

Bipolar plates in the PEMFC have traditionally been made from graphite, since graphite has excellent chemical stability to survive the fuel cell environment. Other advantages of graphite are its excellent resistance to corrosion, low bulk resistivity, low specific density, and low electrical contact resistance with electrode backing materials. This low contact resistance results in high electrochemical power output. The disadvantages of graphite plates are its high costs, the difficulty of machining it, its porosity, and its low mechanical strength (brittleness). Bipolar plates have traditionally been created from graphitic carbon impregnated with a resin or subject to pyrolytic impregnation. A thermal treatment is used in the process to seal the pores. This seal renders the bipolar plates impermeable to fuel and oxygen gases. Due to the brittle nature of graphite, graphite plates used in fuel cell stacks must typically be several millimetres thick, which add to the volume and weight of the stack.

In order to solve this problem, flexible graphite was considered the material of choice for bipolar plates in PEMFC. Flexible graphite is made from a polymer/graphite composite, in 
which the polymer acts as a binder. The graphite principally used for the composite is expanded graphite (EG), produced from graphite flakes intercalated with highly concentrated acid. The flakes can be expanded up to a few hundred times their initial volume ${ }^{[20]}$ produced from graphite flakes intercalated with highly concentrated acid. The expansion leads to a separation of the graphite sheets into nano-platelets with a very high aspect ratio. This layered structure gives higher electrical and thermal conductivity. The expanded form is then compressed to the desired density and pressed to form the bipolar plate. In comparison to conventional graphite bipolar plates, the bipolar plates produced from EG are thinner.

\subsection{Polymer composite bipolar plates ${ }^{[10,17]}$}

Thermoplastic or thermosetting composites are beneficial over metallic and traditional graphite materials with regard to corrosion resistance, flexible and low weight. In addition, polymer composites may be produced in economical processes, such as compression, transfer or injection moulding processes, depending on the number of units to be manufactured. The main drawback to polymer composite is the lack of electrical conductivity, which is critical independently of final applications. To enhance the electrical conductivity of the bipolar plates, electrically conductive polymeric materials have been used as bipolar plate materials. Electrically conductive polymeric materials are organic based materials that permit electron transfer.

According to the electrically conductive structure, conductive polymeric materials can be divided into two categories: intrinsically conducting polymers (ICPs) and conductive polymeric composites (CPCs). ICPs are organic polymer semiconductors. Electrical conductivity is realized by the presence of chain unsaturation and electron delocalization effects. Much research effort and interest has therefore been devoted towards the development of polymers with intrinsic electrical conduction characteristics brought about by the presence of the conjugated group and by doping techniques. ICPs can be used for few applications due to their poor productivity and the high manufacturing costs, although they own terrific conductive performance. In terms of CPCs, composite materials for bipolar plates can be categorized as metal or carbon-based. The combination of conventional polymers (ABS, PC, PP, and etc.) with conductive loads of fillers (e.g. carbon black or carbon fibers, metallic or metallic fibers, metallic powders) allows the creation of new polymeric composite materials with unique electrical properties. CPCs are advantageous over ICPs with regards to because of the large-scale variation in the conductivity, the favorable processability and low costs. However, CPCs would not be unsuccessful to improve conductive and mechanical performance simultaneously for the reason that high filler concentration improves on conductive performance but it deteriorates on mechanical performance.

In spite of the well created commercial products available to the fabrication of a polymer composite bipolar plate (Figure 4), there is a continuous attempt for the development of better composites with maximized electrical conductivity.

\section{Electrically conductive thermoplastic composites}

Typically, polymer composites are created by incorporating a conductive material into a polymer matrix. The preference for the polymer binder is governed by the chemical compatibility with the fuel-cell environment, mechanical and thermal stability, 
processability when loaded with conductive filler, and cost. Two different main types of resins have been used to fabricate composite plates: thermoplastic and thermosetting. Among the thermosetting resins, such as phenolics, epoxies, polyester, and vinyl ester, etc., the epoxy resin is a popular choice for a polymer composite bipolar plate production [6]. The thermosetting resins have low viscosity, and thereby contain a higher proportion of conductive fillers. During the moulding process, the thermosetting resin allows for moulding of intricate details. Moreover, the resins can be highly cross-linked through a proper curing process, and the cross-linked structure gives good chemical resistance [3].

Thermoplastic resins, such as polypropylene (PP), polyethylene (PE), poly (vinylidene fluoride) (PVDF), liquid crystalline polymer (LCP), poly (phenylene sulfide) (PPS), and fluoropolymer[6]are used less in bipolar plate fabrication than thermosetting resins for various reasons. These reasons are: thermoplastics are generally less chemically stable as thermosets and a fuel cell must be operated at lower temperatures to avoid plates melting. On the other hand, they can be injection-moulded and are therefore more beneficial in automated manufacturing. This process is suitable for mass production for future markets. However, high filler loadings limit possibilities for the injection moulding process because of the higher viscosity of the composite material. As a consequence, thermoplastic composites generally have lower electrical conductivity than other technologies. The pathway to modify such advanced materials is to incorporate conductive fillers in the thermoplastic matrix with a proper conductive network structure. This review mainly discusses about the development of thermoplastic/conductive carbon filler composites which is CPCs. A comparison between a thermoplastic/filler composite and a thermoset/filler composite for the bipolar plate material is shown in Table 2.

\section{Thermoset/filler composite Thermoplastic/filler composite}

$\begin{array}{lll}\text { Advantage } & \text { - Higher temperature } & \text { - Injection moulding lends itself to } \\ & \text { operation than thermoplastic } & \text { manufacturing automation } \\ & \text { - Fast cycle-time } & \text { - Fast cycle-time } \\ & \text { - Flow-field introduced during } & \text { - Flow-field introduced during } \\ \text { moulding } & \text { moulding } \\ \text { - Low contact resistance } & \text { - Low contact resistance } \\ \text { Disadvantage } & \text { - Relatively low electrical } & \text { - Low electrical conductivity } \\ \text { conductivity } & \text { when using standard } \\ & & \text { thermoplastics } \\ & & \text { - Limited to low-temperature } \\ & \text { operation } \\ & \text { - Injection moulding difficult at } \\ & \text { high filler loading } \\ & \text { - Generally less chemically stable } \\ & \text { than thermoset resin- } \\ \text { Processing option } & \text { - Injection moulding } \\ & \text { - Pompression moulding } & \text { - Compression moulding } \\ \text { blank } & \text { - Post-moulding CNC milling of } \\ & \text { blank }\end{array}$

Table 2. A comparison between a thermoplastic/filler composite and a thermoset/filler composite for the bipolar plate material [3] 
An important theory for understanding conductivity within thermoplastic composite materials, especially where the thermoplastic matrix and the fillers have very different characteristics, is the concept of percolation. Percolation processes were developed by Flory (1941) and Stockmayer (1943) to describe how small branching molecules react and form very large macromolecules [22]. In a view of electrical conduction in a polymer matrix, electrons are free to flow through conductive filler particles. If these filler particles contact one another, a continuous path is formed through the polymer matrix, which is an insulating material, for electrons to travel through. This path is called a conductive network, and the material with the conductive network turns into a conducting material, as illustrated in Figure 5.

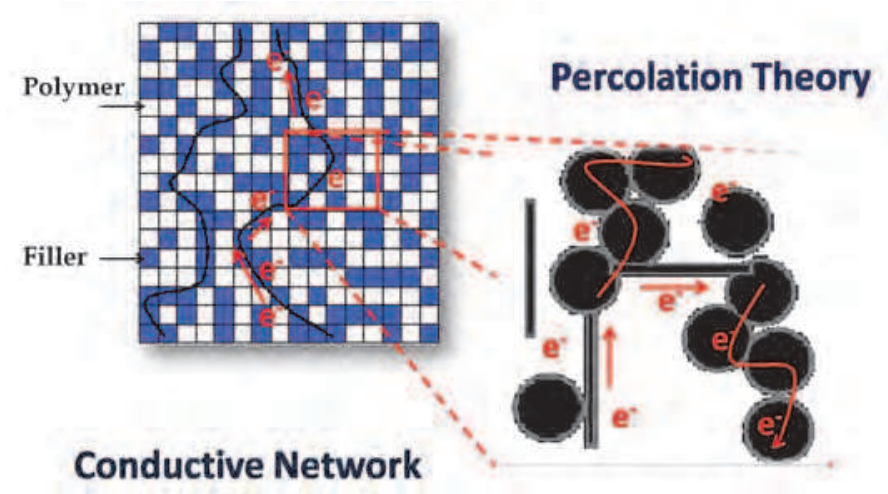

Fig. 5. Schematics of percolation pathway[11]

For the increase in conductive filler loading, three main regions define the relationship to the conductivity of conductive-filled-polymer composites as shown in Figure 6. At low filler loadings (region A), the electrical conductivity value equals zero, since no path exists for electron transport. The conductivity of the composite is still very close to that of the pure polymer matrix. At a certain critical loading, known as the percolation threshold, enough filler has been introduced so that it begins to form a continuous conductive network through the composite. Following the percolation threshold is a region that produces a significant increase in conductivity with very little increase in filler amount, as displayed by region B. After this region of drastic increase, the conductivity slows its increase, and approaches that of the filler material as increase happens because the conductive network through the sample is complete. This is depicted in area C of Figure 6. Eventually, $\mathrm{P}_{\max }$ is reached, at which point the addition of more filler does not increase the ease of electron movement. The addition of more filler will not enhance the conductivity to any significant degree.

In this chapter, different aspects of percolation phenomena of several polymer systems are reviewed. The information in this chapter is closely related to the electrical performance of CPCs and it may be useful for the improvement of thermoplastic composite bipolar plates.

To investigate the possibility of using conductive composite blends as bipolar plates in PEMFC, electrical conductivity and fuel cell performance must be characterized. Prior to discussing the development of electrically conductive thermoplastic composites, it is essential to understand the concepts of electrical conductivity and fuel cell performance measurements. 


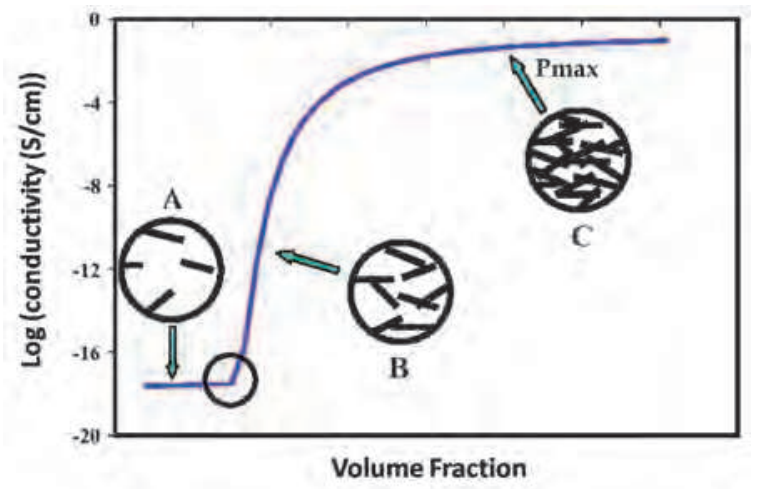

Fig. 6. Percolation S-Curve[23]

\subsection{Electrical conductivity measurements}

According to PEMFC operation, electrons must transfer through bipolar plates to complete a circuit (Figure 7), so one critical fuel cell performance factor is the electrical conductivity of the bipolar plate. The better the electrical transport of a bipolar plate, the fewer plates are required to produce a given power output.

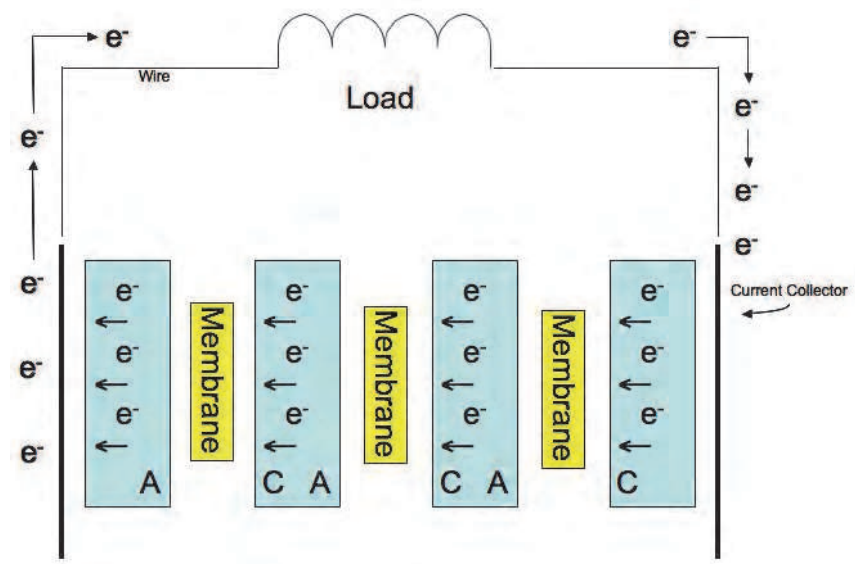

Fig. 7. Schematic of electron transport in the cell [11]

Two main methods, through-plane and in-plane conductivity measurements, are employed to measure the electrical conductivity of composite plates. The through plane test method [24], developed by the US Fuel Cell Council, can measure bulk resistance and contact resistance. Both result in a voltage drop across bipolar plates. Bulk resistance is that of the bipolar plate material, and contact resistance is that of the bipolar plate and gas diffusion layer interface. To measure the through-plane conductivity, a composite specimen is placed between two conducting plates (gold-nickel-copper plates). A current source is applied through those conducting plates and the voltage drop across two conducting plates is measured with a multimeter. In a typical fuel cell, the stack of bipolar plates is held under 
pressure to seal the interfaces. Stress affects the electrical characteristics of the bipolar plate material; therefore, to measure the conductivity of a bipolar plate, a sample must be placed under pressure (Figure 8).

The conductivity can be calculated using Ohm's law (Equation 4)

$$
\text { Electricalconductivity }=\frac{I}{V} \times \frac{(\text { samplethickness }(\mathrm{cm}))}{(\text { width }(\mathrm{cm}) \times \operatorname{length}(\mathrm{cm}))}=S_{c m}(-1)
$$

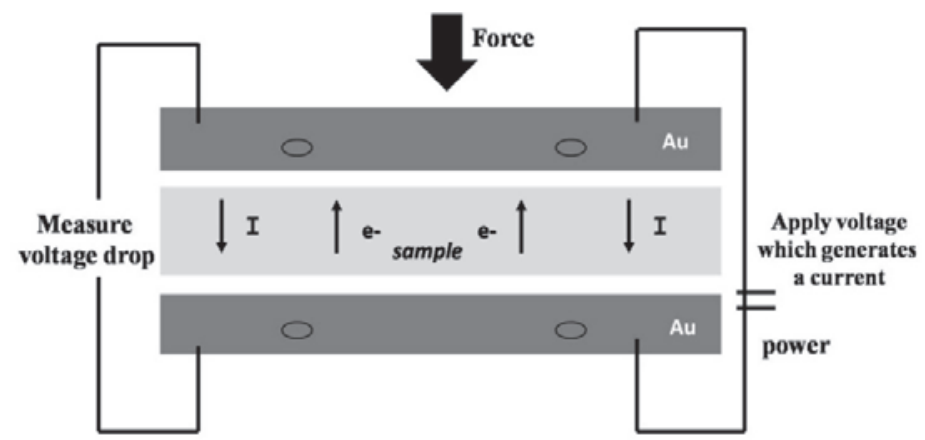

Fig. 8. Basic setup for through-plane conductivity test method[11]

Typically, a four-point probe is used to measure the in-plane electrical conductivity [25] of bipolar plates. This tool supplies excellent measurement results for near-surface and surfacerelated electrical properties of bipolar plates. However, it does not provide the same insight into electrical characteristics deep inside the bipolar plate (Figure 9). The four probes are arranged in a linear fashion, where the two outer probes are connected to a voltage supply, and the inner probes to a volt meter. As current flows between the outer probes, the voltage drop across the inner probes is measured. The relationship of the current and voltage values is dependent on the resistivity of the material under test, and the geometrical characteristics of the probes.

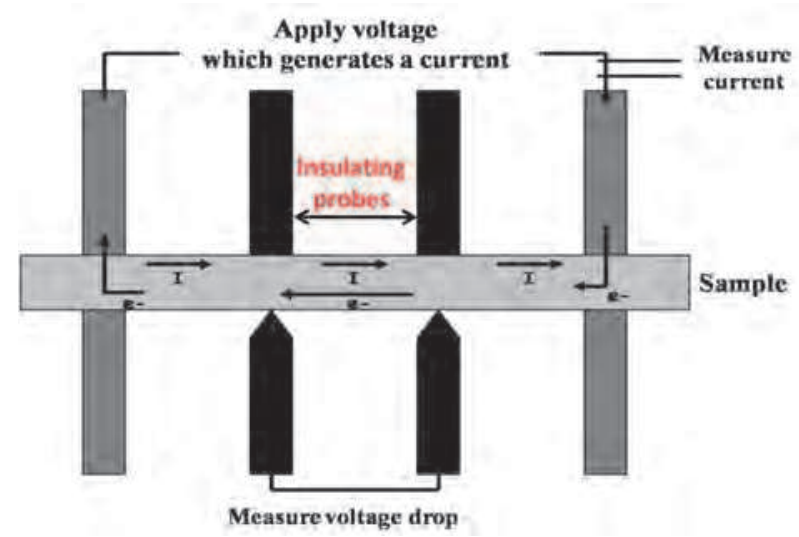

Fig. 9. Four point probe tester[11] 
Using a rectangular sample, Mironov ${ }^{[25]}$ calculated the resistivity relating to two geometric correction factors: a rectangular specimen of thickness (F1) and a rectangular specimen of length (F2).

$$
\rho=\frac{\pi T}{\ln 2}\left(\frac{V}{I}\right) F_{1} F_{2}
$$

\subsection{Fuel cell performance measurement ${ }^{[2,5]}$}

The quality and functionality of fuel cells and their components can be evaluated in terms of conductivity, mechanical strength, permeability, reliability, durability, and power output. A polarization curve is the important indicator of overall fuel cell performance (Figure 10). The plotted curve relates the cell voltage to a changing current density. The maximum cell voltage, which occurs when the current density is zero, is referred to as the open circuit voltage $(\mathrm{OCV})$. In electrochemical systems the voltage decreases as the current density increases and can be divided into three general areas: activation polarization, ohmic polarization, and concentration polarization. As shown in Figure 10, at the OCV, no power is produced. The power then increases with increasing current density up to a maximum, the position of which depends on the design and quality of the fuel cell components employed. Beyond the maximum, the drop in cell voltage is stronger than the increase in current density. The overall fuel cell performance is given in Equation (6), which signifies the cell voltage as the ideal Nernst voltage $\left(\mathrm{E}^{\circ}\right)$ minus different sources of voltage loss $(\eta)$.

$$
V_{\text {Cell }}=E^{\circ}-\eta_{\text {activation }}-\eta_{\text {ohmic }}-\eta_{\text {concentration }}
$$

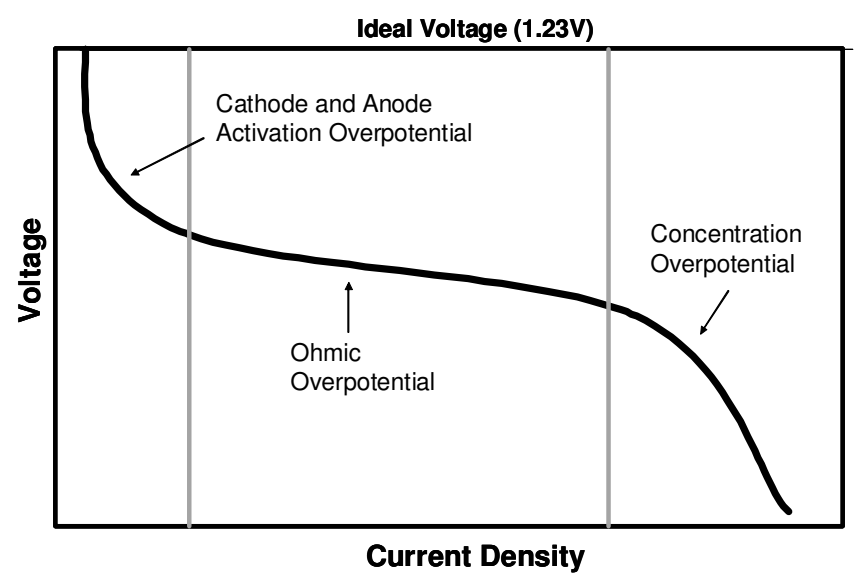

Fig. 10. Regions of a polarization curve

According to percolation phenomena, the intrinsically insulating polymer resin must be filled with conductive particles to meet the conductivity requirements for bipolar plate use. For example, Cokturk et al. [26] prepared composite materials by incorporating various nickel fillers of different shapes into polyethylene. The nickel-fillers used in this project were nickel 
powders, nickel filamentary powders, nickel flakes, and nickel-coated graphite fibres. It was found that the volume resistivity values of the composite materials, at maximum filler volume fraction ( $67 \mathrm{vol} \%$ ), decreased more than 17 orders of magnitude with respect to neat polyethylene. A composite bipolar plate made from polyvinylidene fluoride (PVDF) as the binder and titanium silicon carbide $\left(\mathrm{Ti}_{3} \mathrm{SiC}_{2}\right)$ as the conductive filler was fabricated by a compression moulding technique. The metallic filler was able to improve electrical conductivity to $28.83 \mathrm{Scm}^{-1}$, but it did not meet all the criteria [27]. Instead, poor dispersion and wetting of nickel coated-graphite in the polypropylene matrix were observed [28]. The poor dispersion and incompatibility of materials lowered the electrical conductivity when compared to the blend with synthetic graphite. This result implied that the procedure for the polymer-metal filler system needs improving to produce better dispersion composites. Moreover, the polymer-metal filler composites have the potential for ion dissolution into the fuel cell membrane, degrading performance.

To solve this problem, researchers mixed a polymer with corrosion-resistant conductive particles that do not leach and thus met the conductivity target. In summary, conductive carbonaceous fillers have proven to be interesting fillers for polymer composite bipolar plates.

\subsection{Electrically conductive carbonaceous fillers}

Graphite has been incorporated into polymers for bipolar plate purposes since it is able to enhance electrical properties and may offer attractive electrochemical, physical, mechanical, and economic possibilities. To reach target electrical conductivity, a high load of graphite $(60-80 \mathrm{wt} \%)$ was must be formulated for the bipolar plate material. For example, the graphite composite bipolar plates in the research of Heo and his collaborators were composed of expanded graphite, graphite flake and a novolak-type phenol resin, with a 75:25 wt \% ratio of graphite to phenol [29]. The production involved pre-curing and compression moulding processes. The results indicated an electrical conductivity of 250 $\mathrm{Scm}^{-1}$, which met the requirements for PEMFC bipolar plates. According to the requirement of high graphite loading, thermosets are a popular polymer matrix used in graphite/ polymer bipolar plates, since they can accommodate a higher proportion of conductive graphite [30,31].

Although thermoset/graphite composites are more preferable for using as a bipolar plate material than thermoplastic/graphite composites, scientists and engineers have been attempting to employ thermoplastics for the graphite composite bipolar plates. The main advantage of using thermoplastics is that they can be injection-moulded and are more favourable to automated manufacturing. High temperature thermoplastic graphite composites were therefore prepared using polyphenylene sulfide (PPS) and polyether sulfone (PES) containing natural graphite powder [32]. A low resistance, in the order of 0.1 ohm, was obtained for a graphite concentration of $50 \mathrm{wt} \%$. PPS/G composite with $20 \%$ PPS resin content could be produced under a moulding temperature of $380{ }^{\circ} \mathrm{C}$ [33]. The bending strengths of the composites are $52.4 \mathrm{MPa}$ and $55.7 \mathrm{MPa}$, when the electrical conductivities of the composites are $118.9 \mathrm{~S} \mathrm{~cm}^{-1}$ and $105 \mathrm{~S} \mathrm{~cm}^{-1}$, respectively. The values can meet the requirements of DOE standard at the same time (Figure 11). The plate had an electrical conductivity of $118.9 \mathrm{Scm}^{-1}$. Xiao et al. [20] first prepared a poly (arylenedisulfide)/graphite nanosheet composite via a direct ring opening polymerization, and then graphite nanosheets were prepared by ultrasonic bathing. The plate produced was a good candidate for the bipolar plates of a PEMFC. 

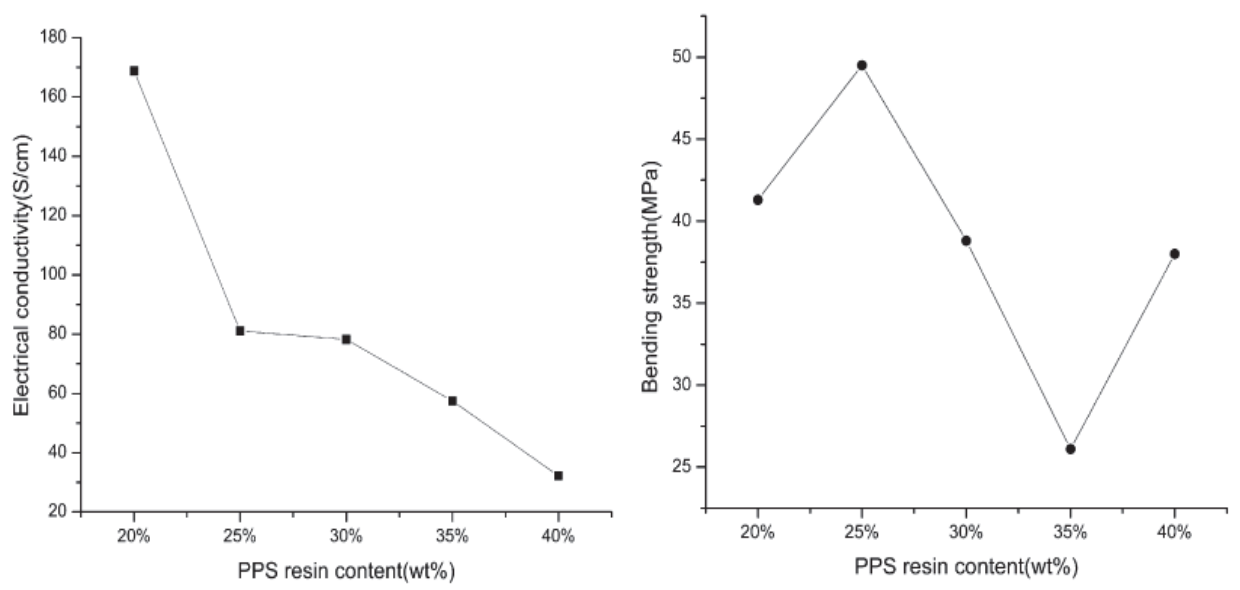

Fig. 11. Effect of PPS content on electrical conductivity and bending strength of the PPS/graphite composites[33]

Carbon black (CB)-filled thermoplastic composites are widely used as antistatic and electrostatic dissipative and semi-conductive materials. To increase the electrical conductivity, polymers with high carbon powder loading have been explored. Carbon black compounds are typically loaded with $30 \%$ to $40 \%$ carbon black because CB-filled polymers have relatively low-bulk electrical conductivities, most of which were below $1 \mathrm{Scm}^{-1}$ [34]. Del Rio et al. used polyvinylidene (PVDF) and carbon black to achieve a conductivity of 2.36 $\mathrm{Scm}^{-1}$, corresponding to PVDF with $40 \mathrm{wt} \% \mathrm{CB}$ at $30^{\circ} \mathrm{C}$, for example ${ }^{[35]}$. When the CB content changed from 30 to $40 \mathrm{wt} \%$, a sudden rise in conductivity was observed. The conductivity increased because the percolation threshold appeared just at this range. The best results from a performance test of a conventional fuel cell using these composite bipolar plates were obtained with the highest CB concentration $\left(100 \mathrm{mWcm}^{-2}\right.$ at $\left.200 \mathrm{mAcm}^{-2}\right)$. Although carbon black can increase conductivity, the addition of carbon black diminishes processability of the material. An additional problem associated with high CB concentrations in polymers is the substantial reduction in the strength and ductility of the polymer composites [36]. To address such problems, numerous studies were directed at reducing the carbon black concentration and the percolation threshold. Gubbels and his co-workers ${ }^{[37}$ proposed a concept of a triplecontinuous structure to provide carbon-filled polymer blends with high electrical conductivity and tensile strength simultaneously. They found that the conductive carbon is preferentially located in one phase and forms a triple-continuous structure which has the advantage of achieving conductive composites at lower carbon concentrations. It is because only the percolation threshold in one phase needs to be exceeded, rather than the entire polymer blend (Figure 12).

Even though fibres are frequently used to improve the strength and rigidity of polymers, several studies have considered the reinforcement of thermoplastic polymers using carbon fibres to achieve improve the thermal and electrical properties. Fibres with finite aspect ratios can enhance the conductivity of a composite by aligning the long and more conductive axis of fibre particles in the current-flow or "through-thickness" plate direction. The fibre particles make smaller and fewer insulating gaps in the composite, resulting in a material resistivity reduction and, in turn, an increase in conductivity [38]. To consider the 
influence of fibre loading on electrical and mechanical properties, some studies have been performed on fibre orientation. Clingerman and his team ${ }^{[39]}$ performed compounding runs followed by injection moulding of test specimens of carbon fibres filled nylon 6, 6 and polycarbonate based polymer. They found that the difference in electrical conductivity was likely due to the higher length, aspect ratio, and orientation of the carbon fibres in the composites. Carbon nanotubes are one type of carbon fibres that have been used to enhance an electrical property of bipolar plates. Liao, S.H. and his co-workers [40] fabricated thin nanocomposite bipolar plates (the thickness $<1.2 \mathrm{~mm}$ ) including multiwalled carbon nanotubes, graphite powder and polypropylene (PP). They used three types of PP with different crystallinities including high crystallinity PP, medium crystallinity PP, and low crystallinity PP to investigate the influence of crystallinity on the dispersion of MWCNTs in PP matrix. The results showed that the dispersion of MWCNTs in low crystallinity PP is favoured. Since highly crystalline polymers have strong van der Waals forces between intermolecular chains, MWCNTs tend to aggregate within the matrices.

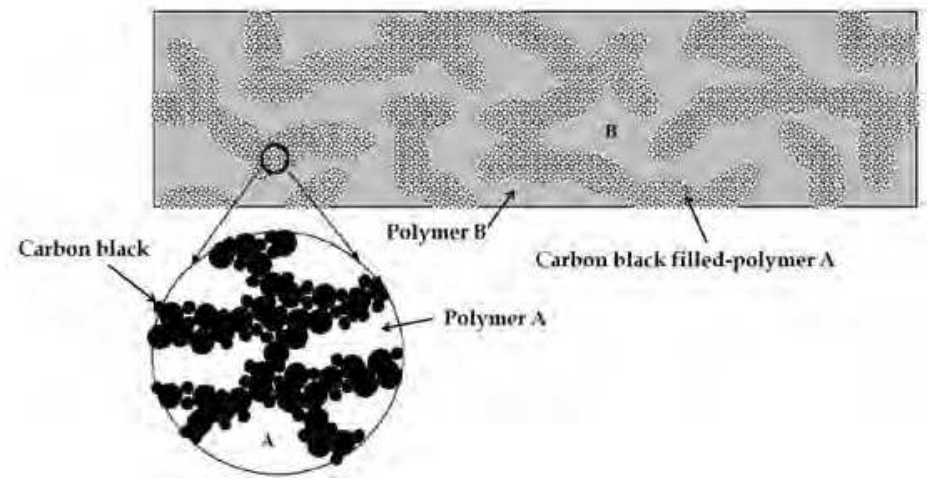

Fig. 12. Schematic of the microstructure of the proposed carbon black-filled polymer blend composite[35]

The addition of various carbon fillers with different physical and electrical properties, including natural flaky graphite, synthetic graphite, carbon black and carbon fibres, were found to be essential for the development of bipolar plates with the desired properties [31]. The single filler gives typical blend characteristics as follows. Carbon black has a high surface area and aggregation behaviour, which are needed to achieve the desired conductivities and are also responsible for relatively low production cost. It is difficult, however, to prepare well dispersed polymer/carbon black composites containing more than $35 \mathrm{wt} \%$ carbon black. As a result, graphite is generally added to the composite to combine the electrical properties of graphite with ease of processing. High-aspect-ratio carbon fibre has also been added to polymers to increase both electrical conductivity and mechanical reinforcement. Therefore, the synergistic effect, which results from combining various types of conductive fillers, on electrical conductivity is a topic of growing interest to researchers. In previous works, the use of two filler types in polyethylene composites combined the conducting features of carbon black and carbon fibre [41]. While fibres provide charge transport over large distances, carbon black particles improve inter-fibre contacts. The results showed that for composites in which the segregated carbon black-polyethylene component was laid above the percolation threshold, the electrical inter-fibre contacts were 
activated through carbon black particle bridges, leading to a rise in conductivity. The addition of sufficient amounts of carbon black must be controlled to obtain good processability. Therefore, graphite was used instead of carbon black to overcome this disadvantage. Radhakrishnan[32] stated that the addition of carbon black component led to further improvement in electrical conductivity over and above that achieved at high graphite contents (Figure 13).
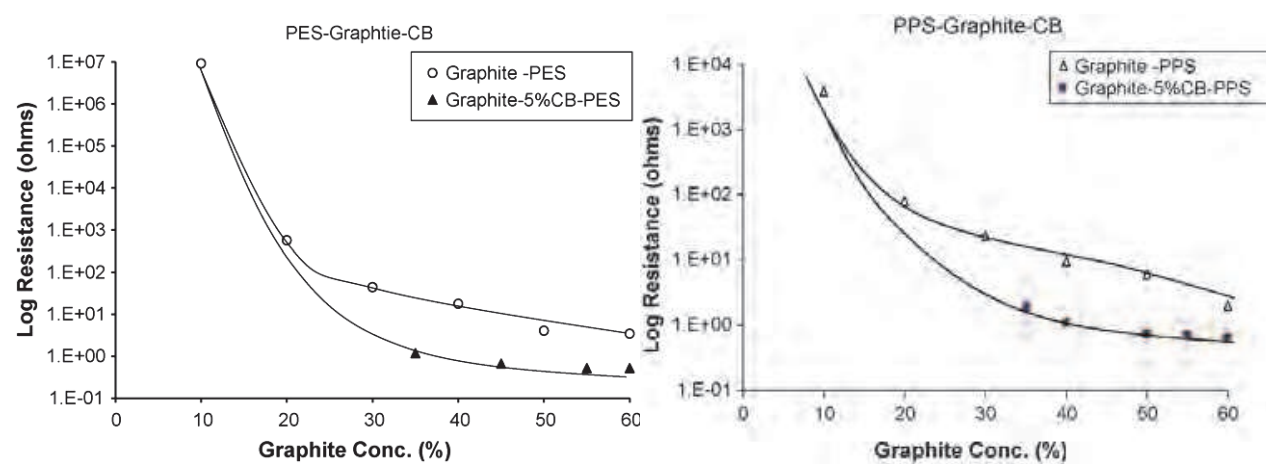

Fig. 13. Compositional dependence of electrical resistance of graphite composites [32].

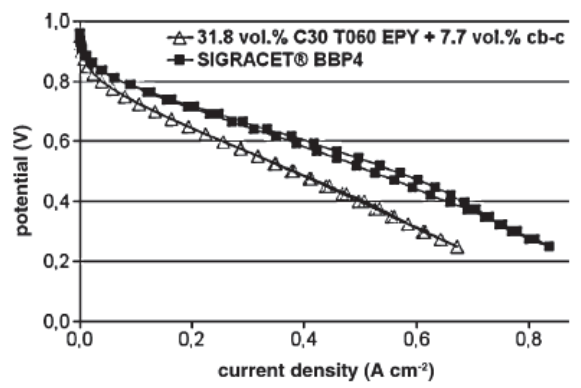

Fig. 14. Current-voltage characteristic curves of a bipolar plate of composite bipolar plate.

Wolf and Willert-Porada[42] blended Ticona (Liquid crystal polymer (LPC)) with $31.8 \mathrm{vol} \%$ of carbon fibre and $7.7 \mathrm{vol} \%$ of carbon black. The current-voltage characteristic curve (Figure 14 ) of the composite was compared with a commercial composite material (SIGRACET® BBP4). The maximum current density of the assembly containing the composite bipolar plates was $20 \%$ below the maximum current density of the assembly containing the commercial product, which consists of more than twice the amount of carbon. Ternary composites were also used as electrically conductive materials to prepare bipolar plates. Huneault formulated a new material using polypropylene (PP) and polyphenylene sulfide (PPS) as matrices and carbon black, graphite, and carbon fibres as conductive additives [43]. The University of Waterloo has investigated the synergistic effect of two and three filler systems on bipolar plate properties [11, 23, and 28]. Conductive networks in composites can be associated by the combination of carbon fillers as shown in Figure 15.

These formulations have properties suitable for bipolar plate manufacturing. The University of Duisburg-Essen together with the Zentrum für BrennstoffzellenTechnik GmbH (ZBT) 
produced carbon fillers-thermoplastic composite bipolar plates using injection moulding process. The bipolar plates had density of $1.6 \mathrm{gcm}^{-3}$, specific bulk conductivities $150 \mathrm{Scm}^{-1}$ and material prices between 2 and 10 Euro $\mathrm{kg}^{-1}$. Even though, the investigations showed that the electrical conductivity and ability of injection moulding process can be improved significantly, three carbon fillers always resulted in an increased viscosity [44].

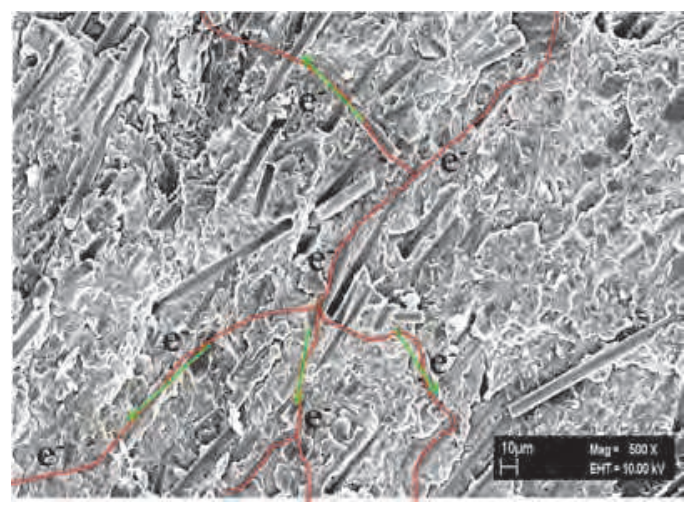

Fig. 15. SEM micrograph of composite with carbon fibre, synthetic graphite, and carbon black using magnification of 500X[11]

In composite bipolar plates, the filler should extend continuously along the cross sectional area and through the thickness of the plate. In other words, the composite needs appropriate conductive networks to have enough electron transport paths. However, several obstacles exist, such as adhesion failure, agglomeration, and poor distribution of fillers in the matrix. Furthermore, filler distribution may increase contact resistance if the conductive filler does not fully disperse to reach the surface. The introducing of coupling agents is one technique for formulating well dispersed polymer/filler composites. A coupling agent can act as a molecular bridge at the interface between the two substrates; hence, it improves the interfacial adhesion between fillers and the matrix [45]. It also plays the role of a dispersion agent; thus, it increases the probability of conductive network formation throughout the matrix. Improvement in the electrical conductive network will diminish the percolation threshold. For example, the electrical percolation of polyethylene/carbon black composite decreases when CB is treated by a titanate coupling agent [46]. Polymer composites prepared as a mixture of a conjugated conducting phase and classical nonconducting phase can exhibit good electrical conductivity with relatively low conducting phase content. They normally show a significant jump in the electrical conductivity at a certain critical concentration of the conducting polymer. The possibility of using conductive polymers to produce bipolar plates is an interesting notion for fuel cell development. For example, an exploration was made of the electrical properties of polypropylene/conductive filler (i.e., graphite, carbon black, and polyaniline) composites as potential replacements for the traditional graphite bipolar plates [47]. Two methods were mainly adopted in this work for the preparation of composites: melt compounding and solution blending. The results indicated that the solution blending led to further improvement in electrical conductivity compared with the melt compounding. Yeetsorn and collaborators [48] found that using polypyrrole (PPy) as an additive was also successful in further improving electrical 
properties of the composites through better dispersion, as well as contributing to the conductive network. The results indicated that PPy improved PEMFC performance by improving the electrical conducting network within the composites (Figure 16). PPy acts as a conducting additive dispersing on the interface between fillers and the polymer matrix, and it can also coat some parts of filler surfaces. These functions of PPy improve the number of conductive paths ${ }^{[11]}$.
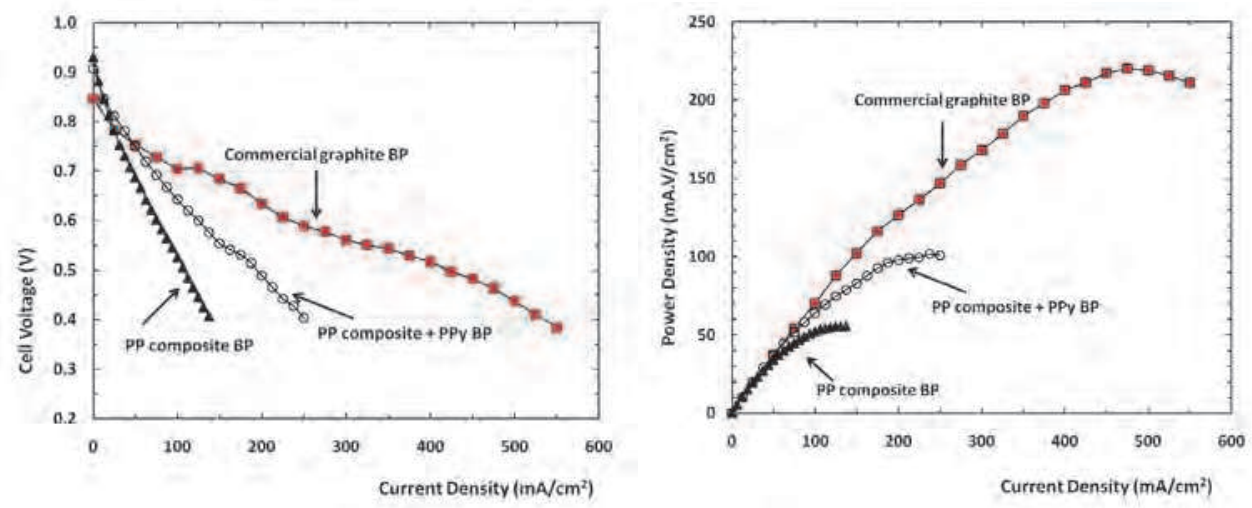

Fig. 16. Initial performance of the single cells assembled with different bipolar plates[11]

\section{Thermoplastic composite bipolar plate manufacture ${ }^{[15,49, \text { and } 50]}$}

From a processing point of view, the polymer composites offer ease of manufacturing. For instance, flow fields can be moulded directly into these composites, thereby eliminating the costly and difficult machining steps required for graphite or metal hardware. The composites are used to form bipolar plates with flow channels by conventional compression or injection moulding or compression-injection moulding.

Compression moulding and injection moulding are two main processes for current manufacturing of bipolar plates. The compression moulding is favoured for both thermoplastic and thermosetting matrix composites. However, if compression moulding is used, the thermoset has to be cured, and the thermoplastic material has to be cooled. Both of these processes greatly increase production time. If compression moulding is used, costeffective mass production would be more readily achievable with thermosets rather than thermoplastics because of the shorter cycle times for thermosets. With a suitable combination and operating condition, a compression moulded thermoset composite can be cured comfortably in less than 10 minutes, resulting in cycle times less than those required for thermoplastics. Injection moulding machines make manufacturing automation and mass-production easier, as well as ensuring short processing times, of as little as 30 seconds per plate, and with high dimensional tolerance. However, in order to accomplish practical electrical conductivities, the thermoplastic has to be highly loaded with conductive fillers, which causes the melt to flow poorly. Higher viscosity of materials has become the main concern for composite bipolar plate manufacturing.

Currently, the injection-moulding industry is well ascertained and responding positively to the bipolar-plate challenge. SGL Technologies $\mathrm{GmbH}$ has been developing different moulding technologies for graphite composite bipolar plates since 1997 [51, 52]. Injection 
moulding of polypropylene and phenolic-bonded graphite compounds has been identified as one of the most promising and cost-effective production processes. A range of low-cost carbon-polymer compounds with specific bulk conductivities between 5 and $150 \mathrm{Scm}^{-1}$ was developed in 2005, and a production line for bipolar plates by injection moulding has been set up.

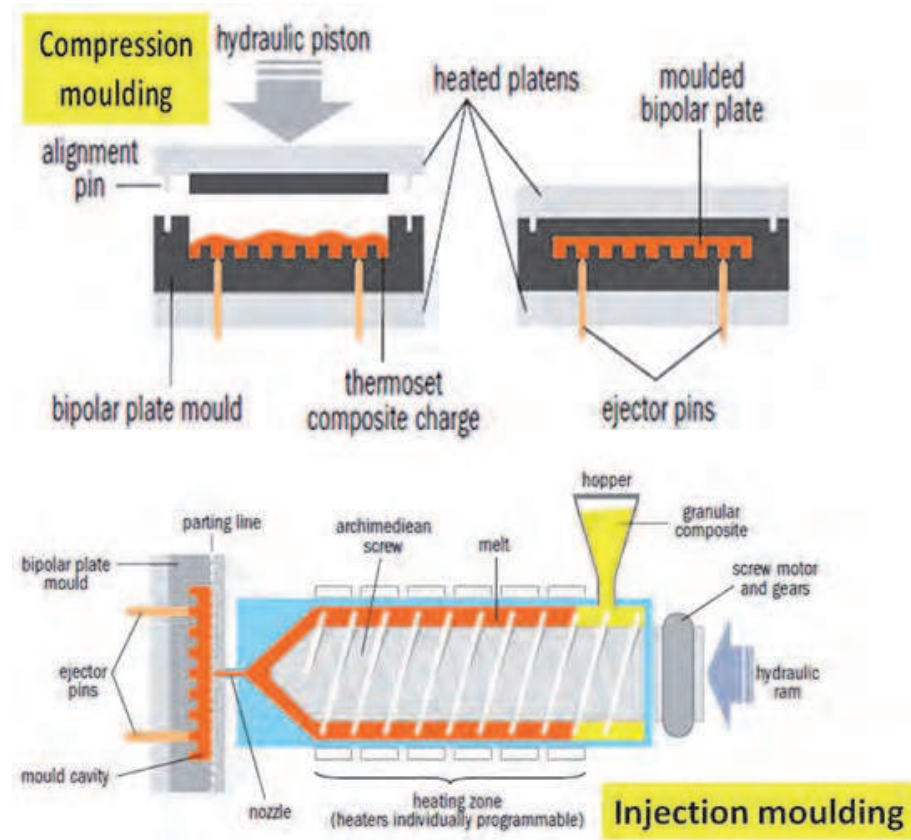

Fig. 17. Compression and injection moulding processes for bipolar plates [3]
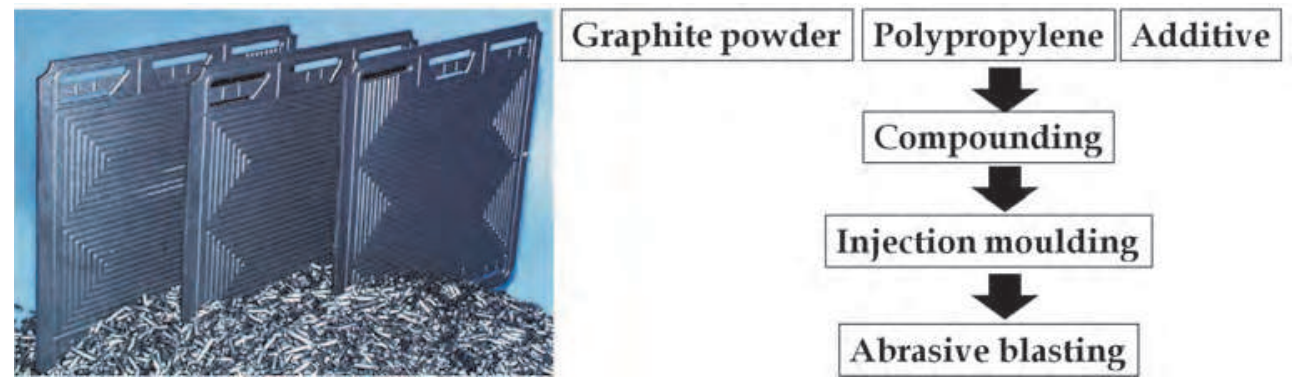

Fig. 18. ${ }^{\circledR}$ Sigracet PPG86 bipolar plates and their production [52]

Quantum Composites (Ohio, US) and Ferromatik Milacron (Germany) were the first to demonstrate injection moulding for a thermoset-based carbon-polymer composite based on vinyl ester. Century Engineering (Michigan, US) has developed RingExtrude (12-screw) which is a technology that modernizes the method by which bipolar plates are produced [3]. An Injection moulding is a low cost high-productivity manufacturing method; however, 
other processes, such as extrusion with appropriated die, rolling and thermoforming may be alternative progressions to producing composite bipolar plates.

Although the injection moulding process favours the massive production rates that are essential to reduce production costs, the electrical conductivity of injected composites is negatively influenced because of the high shearing typical of the process [6].The high shearing promotes the rupture of conductive network structure in the composites. In recent years, some new techniques for prototyping bipolar plates for PEMFC have been reported to avoid the handicaps of injection moulding but faster than conventional compression moulding. Huang and his collaborators used the wet-lay method to make bipolar plates. This method produced wet-lay sheets or mats consisting of graphite particles, glass or carbon fibres, and a base made of poly(phenylene sulfide) [53, 54]. The process was comprised of a slurry-making process and then compression moulding to form conductive composite plaques. The use of the wet-lay composite in the formation of bipolar plates has multiple advantages. First, it increases in-plane conductivities of the composite plate significantly, $200-300 \mathrm{~S} \mathrm{~cm}^{-1}$, while maintaining through-plane conductivity. Second, it dramatically increases the mechanical properties of the composites. Third, one can use different components, including polymers, graphite particles, and reinforcement, for the core and outer layers of the plate, respectively, to optimize the properties and/or reduce the cost of the plate. Kuo and Chen created bipolar plates using a composite material composed of Nylon-6 and S316L stainless steel alloy fibres by the injection moulding process [55].

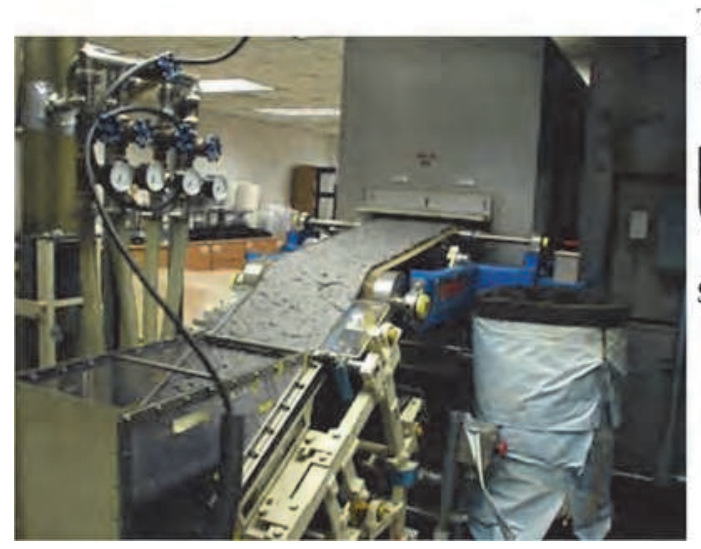

Thermoplastic fibers, carbon fiber, graphite, water

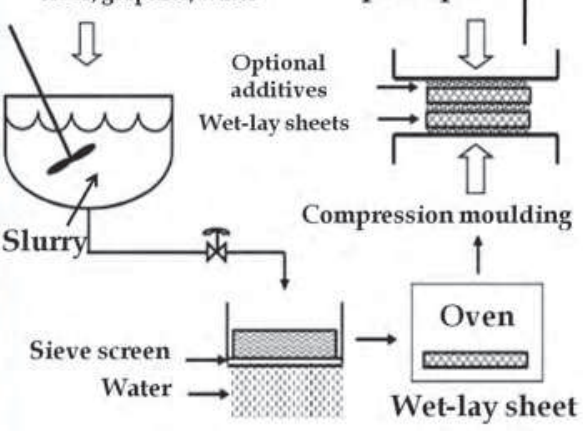

Fig. 19. Manufacture of wet-lay composite sheets and bipolar plates [54]

Although this technique provided a possible alternative to graphite for bipolar plates, the performance of current PEMFC failed to match that of conventional PEMFC with graphite bipolar plates, and metal fibres are likely to impact the durability of moulds and moulding equipment. Inserting metal sheets into bipolar plates is another idea aimed at increasing the electrical conductivity of plates. Hsiao and his team prepared metal mesh hybrid polymer composite bipolar plates by inserting a copper or aluminium mesh in polymer composites [56]. Poly(oxyalkylene)-diamines composites consist of $70 \mathrm{wt} \%$ graphite powder and $0-2 \mathrm{wt} \%$ modified multi-walled carbon nanotubes. Results indicated that the in-plane electrical conductivity of m-MWCNTs/polymer composite bipolar plates increased from $156 \mathrm{Scm}^{-1}$ (with $0 \mathrm{wt} \% \mathrm{MWCNT}$ ) to $643 \mathrm{Scm}^{-1}$ (with $1 \mathrm{wt} \% \mathrm{MWCNT}$ ). However, the aluminium mesh 
hybrid polymer composite bipolar plate exhibits an obvious decrease in through-plane conductivity $\left(22.9 \mathrm{Scm}^{-1}\right)$ due to the passive film layer on the aluminium surface. Prototype plates were successfully fabricated using a two-shot injection over-moulding procedure over aluminium plates [36].

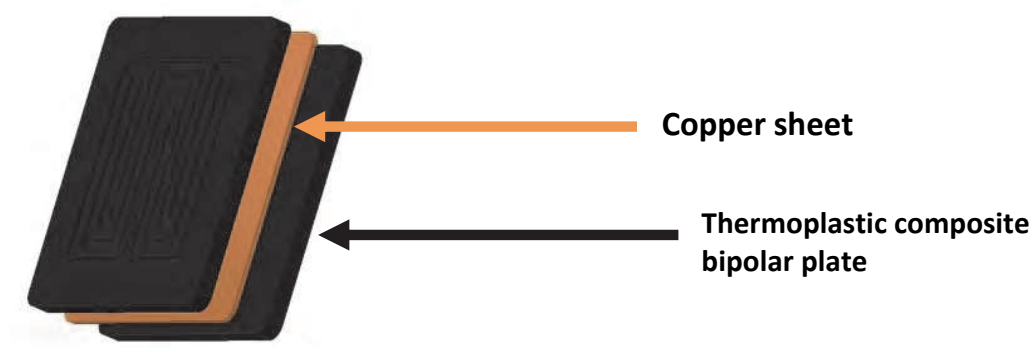

Fig. 20. Copper insert thermoplastic composite bipolar plate

The over-moulding approach is promising, but in order to reduce the contact resistance, improved polymer-metal adhesion and better matching of the aluminium and polymer blend thermal expansion coefficient is required. Direct injection without the metallic core leads to better resistivity results. In the conventional graphite plates, the ribs and channels in the flow fields are formed while removing part of the material to create channels. Thermoplastic composite bipolar plates were fabricated using a two-component moulding process developed by NedStack[57]. The NedStack bipolar plate comprises of two parts which were a highly conductive compound used for the gas-flow-channel area and nonconductive injection moulding grade polymer used for the border area. The two-component moulding process had moulding cycle less than 10 seconds which is 100 times faster than other plate moulding processes. Therefore this short cycle process is considered a break trough in productivity and cost reduction.

\section{Effect of a process condition on electrically conductive network}

The electrical conductivity or other properties of insulating polymer matrices can be increased with relatively high filler compositions of a conductive fill. However, the nonuniformity of material properties is a major problem in a highly filled polymer system due to poor dispersion of fillers in the polymer matrix. Besides filler concentration, the electrical conductivity also depends upon filler dispersion, interaction between composite constituents, and process conditions. Manufacturing processes and processing conditions of composites influence the filler orientation, filler dispersion, and inter-particle distance within the polymer matrix. Furthermore, the processes would change the degree of crystallinity of the matrix and the aspect ratio of conductive fillers [58]. Different systems give different tendencies of changes in electrical conductivity because in reality, the fibre orientation and filler distribution could be due to the complex interactions among many factors during injection moulding ${ }^{[59}$. The filler orientation and dispersion typically affect conductive network association in the blends. The injection parameters, such as injection speeds and melt temperature, strongly affect filler orientation. Chandra and collaborators [60] observed the effects of melt temperature and screw speed on electrical conductivity of polycarbonate/carbon nanotube composites. They stated that in order to achieve uniformly 
distributed high electrical conductivity, the composites should be processed at high melt temperatures and low injection speeds to certify appropriate and uniform electrical conductivities.

Additionally, higher electrical conductivities were found at locations farthest from the gate (Figure 21). Yang and Shi [61] investigated the effect of moulding time on the in-plane electrical conductivity of compression moulded PPS-mesocarbon microbeads composite bipolar plates. The in-plane conductivity increased with moulding time from $10 \mathrm{~min}$ to 30min. The optimum moulding time and moulding temperature may form a threedimensional network that favours the transport of electrons between the conductive fillers.

To accomplish a suitable conductive network structure the processing conditions should be carefully characterized through specific experimental research, regarding both polymer and filler types. Using the simulation of flow injection to describe the conductive network pattern may be useful, as the combination of fillers in a hybrid filled system and various process parameters used in the injection moulding process significantly affect the formation of conductive networks [11, 62]. Yeetsorn and team found the electrical conductivity values of injected bipolar plate cut from different areas of an injected plaque were different, since the electrical conductivity depends largely on the carbon fibre alignment, filler dispersion, and filler distribution.
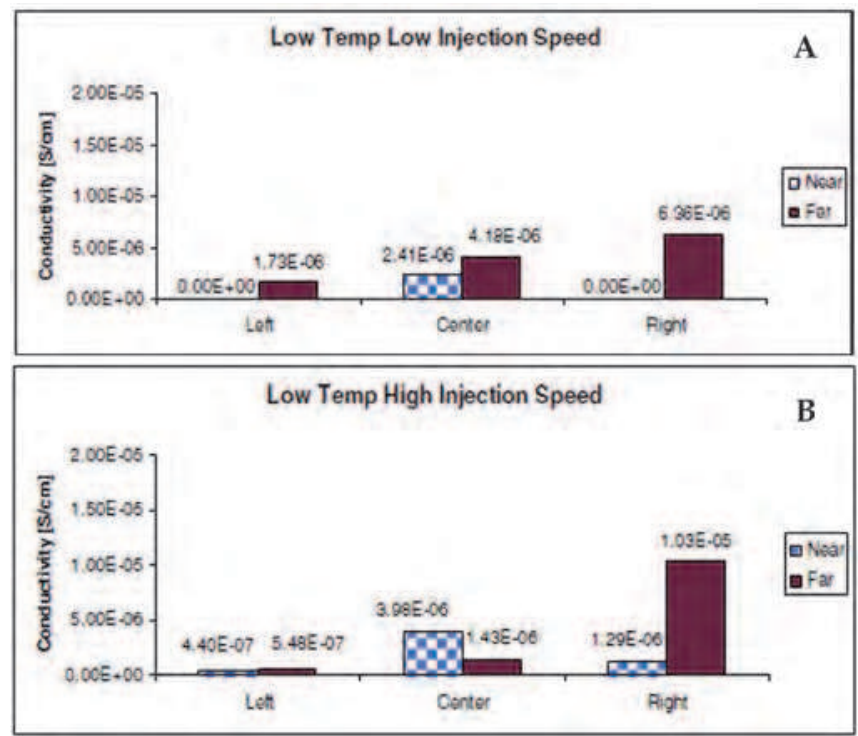

Fig. 21. Electrical conductivities of PC/CNT nanocomposites injection moulded at low melt temperatures (A) low injection speed, (B) high injection speed[61]

Regarding to electrical conductivity values, in-plane and through-plane electrical conductivity of the composite containing only carbon fibres as filler had a positive correlation with the simulation output (Figure 22); however, the final distribution and dispersion of the filler were caused by complex interactions among many factors during injection moulding. Therefore, the simulation output could not explain the orientation of carbon fibres in the composites containing hybrid fillers. 


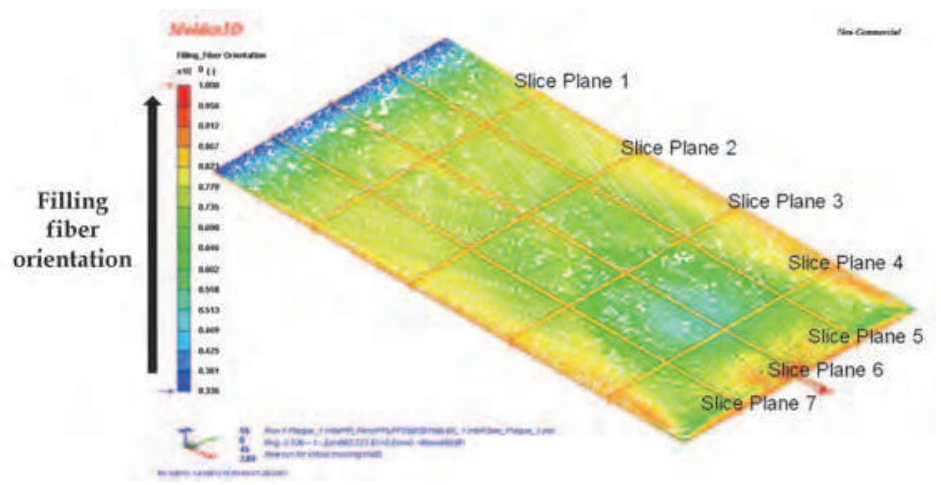

Fig. 22. Simulation output fibre orientation-skin[11]

\section{Conclusion}

Polymer based formulations using thermoset matrix with carbon conductive carbon filler were successful in a PEMFC market, because their electrically conductive performance achieves the DOE target. However thermoset is not suitable for the injection moulding industry which is well established and responding positively to the bipolar plate challenge. Injection moulding has been typically used for thermoplastic products, therefore; thermoplastic composites are promising for future opportunities composite materials within the PEMFC commercialization. An electrical conductivity performance of thermoplastic composite bipolar plates can be satisfactorily modified through the acceptable materials and manufacturing processes. The fundamental concept of conductive composite improvement and the information of material properties are the basic tool to start a successful bipolar plate development for commercialization.

Although, the thermoplastic composites with conductive carbon fillers and conducting additives were successful in further improving electrical properties of the composites, it is important to understand how different carbon fillers behave in thermoplastic matrices due to the percolation theory. The knowledge of the filler and polymer characteristics will be a guideline for the selection of inherent high electrically conductive fillers and less resistive polymeric matrices. Thermoplastic composites with conductive carbon fillers and conducting additives were successful in further improving electrical properties of the composites. These successes are promising for future opportunities composite materials within PEMFCs, even though the developed thermoplastic composite are currently inferior to the performance of commercial bipolar plates. Therefore, there are many factors of thermoplastic composite bipolar plate development that must be concerned and improved as discussed in previous sections to achieve the required properties of bipolar plates. The scientific literatures in this chapter contribute to the development of materials processes and main characterizations of bipolar plates, especially electrical conductivity and fuel cell performance. Ultimately, all information from this article provides a data base for conductive composites and bipolar plate development in academic and commercial fields.

Future directions in the development of thermoplastic composite bipolar plates may be guided by the following recommendations: 
- Investigation of multi filler electrical and rheological percolation thresholds of the composites in multi filler system

- The incorporation of small amount conductive polymer into thermoplastic composites

- Using the simulation of bipolar plate production processes to investigate the effects of operating conditions on conductive network association

- Design an appropriate mould (for injection or compression moulding process) must be provided for conductive network association.

\section{References}

[1] Weaver, G. (2002). World Fuel Cells - An Industry Profile with Market Prospects to 2010, 1st ed., Elsevier, New York, pp. 234.

[2] Barbir, F. (2005). PEM Fuel Cell. 2005, Elsevier Inc, UK:

[3] Brett, D. and Brandon, N., Bipolar Plates: The Lungs of The PEM Fuel Cell. The Fuel Cell Review, Vol. 2, No. 1, 2005, pp. 15-23.

[4] Vishnyakov, V. M. Proton exchange membrane fuel cells. Vacuum, Vol. 80, (2006), pp. 1053-1065.

[5] Larmininie, J., and Dicks, A. (2003). Fuel cell systems explained. Wiley and Sons Ltd., West Sussex, England, John.

[6] Hermanna, A., Chaudhuria, T., and Spagnol, P., Bipolar Plates for PEM Fuel Cells: A review. International Journal of Hydrogen Energy, 2005, Vol. 30, pp. 1297 - 1302.

[7] Steele, B. C. H., and Heinzel, A. Materials for fuel-cell technologies. Nature, 2001, Vol. 414, pp. 345-352.

[8] Kusie, J., Knight, J., and Morton, J. (2010). News Release. Ministry of Transportation and Infrastructure, BC, Canada.

[9] O'Hayre, R., Cha, S.W.,Colella, W.,Prinz, F.B. (2009). Fuel Cell Fundamentals, ed. 2nd., Jonhn Wiley and Sons Inc., New York.

[10] Antunes, R.A., Oliveira, M.C.L., Ett, G., Ett, V. Carbon materials in composite bipolar plates for polymer electrolyte membrane fuel cells: A review of the main challenges to improve electrical performance. Journal of Power Sources, 2011, Vol. 196, No.6, pp. 2945-2961.

[11] Yeetsorn, R. (2010). Development of Electrically Conductive Thermoplastic Composites for Bipolar Plate Application in Polymer Electrolyte Membrane Fuel Cell, Department of Chemical Engineering, University of Waterloo: Waterloo, Canada.

[12] Besmann, T.M., Klett, J. W., Henry, J. J., Lara, C.E., Carbon/Carbon Composite Bipolar Plate for PEM Fuel Cells. Journal of The Electrochemical Society, 2000, Vol 147, No.11, pp. 4083-4086.

[13] Jayakumar, K., Pandiyan, S., Rajalakshmi,N., Dhathathreyan, K.S., Cost-benefit Analysis of Commercial Bipolar Plates for PEMFC's. Journal of Power Sources, 2006, Vol. 161, pp. 454-459.

[14] On, I.B., R. Kirchain, and Roth, R., Technical Cost Analysis for PEM Fuel Cells. Journal of Power Sources, 2002, Vol 109, pp. 71-75.

[15] Mehta, V. and Cooper, J.S., Review and Analysis of PEM Fuel Cell Design and Manufacturing. Journal of Power Sources, 2003., Vol. 114, pp. 32-53. 
[16] Dihrab, S.S., K. Sopian, Alghoul, M.A., Sulaiman, M.Y., Review of The Membrane and Bipolar Plates Materials for Conventional and Unitized Regenerative Fuel Cells. Renewable and Sustainable Energy Reviews, 2009, Vol 13, pp. 1663-1668.

[17] Tawfika, H., Hunga, Y., and Mahajan, D., Metal Bipolar Plates for PEM fuel cell - A review. Journal of Power Sources, 2007, Vol 163, pp. 755-767.

[18] Antunes, R.A., Oliveira, M.C.L., Ett,G., and Ett,V., Corrosion of Metal Bipolar Plates for PEM Fuel Cells: A Review. International Journal of Hydrogen Energy, 2010, Vol. 35: pp. 3632-3647.

[19] Hung, Y., El-Khatib, K.M., and Tawfik, H., Corrosion-resistant Lightweight Metallic Bipolar Plates for PEM Fuel Fells. Journal of Applied Electrochemistry, 2005 vol. 35, pp. 445-447.

[20] Xiao, M., Lub,Y. Wang ,S.J., Zhaoa,Y.F., Menga,Y.Z., Poly(arylene disulfide)/graphite Nanosheets Composites as Bipolar Plates for Polymer Electrolyte Membrane Fuel Cells. Journal of Power Sources, 2006, Vol. 160, No. 1, pp. 165-174.

[21] Ku, C.C. and Liepins, R. (1987). Electrical Properties of Polymers: Chemical Principles., Hanser Publishing, New York

[22] Stauffer, D. (1985). Introduction of Percolation Theory., Tylor and Francis, London.

[23] Mali, T.J. (2006). Thermoplastic Composites for Polymer Electrolyte Membrane Fuel Cell Bipolar Plates, Department of Chemical Engineering, University of Waterloo: Waterloo, Canada.

[24] Cunningham, N., Lefèvre, M., Lebrun, G. and Dodelet, J., Measuring The Throughplane Electrical Resistivity of Bipolar Plates (Apparatus and Methods). Journal of Power Sources, 2005, Vol. 143, pp. 93-102.

[25] Mironov, V.S., Kim J.K., and M. Lefevre, Lebrun,G., Dodelet, J.P., Comparison of Electrical Conductivity Data Obtained by Four-Electrode and Four-Point Probe Methods for Graphite-Based Polymer Composites. Polymer Testing, 2007, Vol. 26, pp. 547-555.

[26] Cokturk, H.S., Fiske, T.J., and Kalyon, D.M., Effects of Particle Shape and Size Distributions on the Electrical and Magnetic Properties of Nickel/ Polyethylene Composites. Journal of Applied Polymer Science, 1993, Vol. 50, pp. 1891-1901.

[27] Bin, Z. and Bingchu, M., Study on The Electrical and Mechanical Properties of Polyvinylidene Fluroide/titanium Silicon Carbide Composite Bipolar Plates. Journal of Power Sources, 2006, Vol. 161, pp. 997-1001.

[28] Wang, Y. (2006). Conductive Thermoplastic Composite Blends for Flow Field Plates for Use in Polymer Electrolyte Membrane Fuel Cells (PEMFC), Department of Chemical Engineering, University of Waterloo: Waterloo, Canada.

[29] Heo, S.I., K.S. Oh, Yun,J.C., Jung, S.H., Yang,Y.C., and Han, K.S., Development of Preform Moulding Technique using Expanded Graphite for Proton Exchange Membrane Fuel Cell Bipolar Plates. Journal of Power Sources, 2007, Vol. 171, pp. 396403.

[30] Kakati, B.K., Deka,D., Differences in physico-mechanical behaviors of resole and novolac type phenolic resin based composite bipolar plate for proton exchange membrane (PEM) fuel cell Electrochim. Acta, 2007, Vol. 52, pp. 7330-7336. 
[31] Mathur,R.B., Dhakate,S.R., Gupta,D.K., Dhami,T.L., Aggarwal, R.K., Effect of different carbon fillers on the properties of graphite composite bipolar plate. Journal of Materials Processing Technology, 2008, Vol. 203, pp.184-192.

[32] Radhakrishnan, S., Ramanujam, B.T.S., Adhikari, A., Sivaram,S., High-temperature, Polymer-graphite Hybrid Composites for Bipolar Plates: Effect of Processing Conditions on Electrical Properties. Journal of Power Sources, 2006, Vol. 163, pp. 702707.

[33] Xia, L. and Li, A., Effects of Resin Content and Preparing Conditions on The Properties of Polyphenylene Sulfide Resin/graphite Composite for Bipolar Plate. Journal of Power Sources, 2008. Vol.178 pp. 363-367.

[34] $\mathrm{Wu}, \mathrm{M}$. and Shaw, L.L., A novel Concept of Carbon-filled Polymer Blends for Applications in PEM Fuel Cell Bipolar Plates. International Journal of Hydrogen Energy, 2005, Vol. 30, pp. 373-380.

[35] Rio, C.D., Rio,C. D., Ojeda, M. C., Acosta, J. L., Escudero, M. J., Hontan, E., and Daza, L., New Polymer Bipolar Plates for Polymer Electrolyte Membrane Fuel Cells: Synthesis and Characterization. Journal of Applied Polymer Science, 2002, Vol. 83,No.13, pp. 2817-2822.

[36] Mighri, F., Huneault, M.A., and Champagne, M.F., Electrically Conductive Thermoplastic Blends for Injection and Compression Molding of Bipolar Plates in The Fuel Cell Application. Polymer Engineering and Science, 2003, Vol. 44, No.9, pp. 1755-1765.

[37] Gubbels, F., Jerome, R., Teyssie, P., Vanlathem, E., Deltour, R., Calderone, A., Parente, V., Bredas, J., Selective localization of carbon black in immiscible polymer blends: a useful tool to design electrical conductive composites. Journal of Macromolecules, 1994, Vol. 27, pp.1972-1974.

[38] Blunk, R.H.J., Daniel, J. L., Yoo,Y.E., and Tucker III, C.L., Enhanced Conductivity of Fuel Cell Plates Through Controlled Fiber Orientation. AIChE Journal, 2003, Vol. 49, No.1, pp. 18-27.

[39] Clingerman, M.L, Weber, E.H., King, J., and Schulz, K.H., Synergistic Effects of Carbon Fillers in Electrically Conductive Nylon 6,6 and Polycarbonate Based Resins. Polymer Composites, 2002, Vol. 23, No. 5 pp.911-924.

[40] Liao,S.H., Yen,C.Y., Weng,C.C., Lin,Y.-F., Ma,C.C.M., Yang,C.H., Tsai, M.-C., Yen,M.Y., Hsiao,M.C., Lee,S.H., Xie,X.F., Hsiao,Y.H., Preparation and properties of carbon nanotube/polypropylene nanocomposite bipolar plates for polymer electrolyte membrane fuel cells.Journal of Power Sources, 2008, Vol. 185, pp. 1225-1232.

[41] Calleja, F.J.B., Bayer, R.K., and Ezquerra, T.A., Electrical Conductivity of Polyethylenecarbon-fibre Composites Mixed with Carbon Black. Journal of Materials Science, 1988, Vol. 23, pp. 1411-1415.

[42] Wolf , H., Willert-Porada M., Electrically conductive LCP-carbon composite with lowcarbon content for bipolar plate application in polymer electrolyte membrane fuel cell. Journal of Power Sources, 2006, Vol. 153, pp. 41-46.

[43] Huneault, M.A., Mighri, F., and Champagne, M.F., Conductive Polymer Blends for Injection Molded Bipolar Plates. Proceedings of ANTEC2003, 2003, pp. 1330-1334. 
[44] King, J.A., Tambling, T. M., Keith, J. M., Cole, A.J., and Morrison, F. A., Synergistic Effects of Multiple Carbon Fillers on The Rheology of Liquid Crystal Polymer Based Resins. Polymer Composites, 2009, Vol. 30, pp. 111-119.

[45] Brovko, Rosso, O.P., and Friedrich, K., Adhesion Between Differently Treated Fibers and A Hybrid Resin System. Journal of Materials Science Letters, 2002, Vol. 21, pp. 305-308.

[46] Yu, G., Zhang, M.Q., and Zeng, H.M., Carbon-black-filled Polyolefine as A Positive Temperature Coefficient Material: Effect of Composition, Processing, and Filler Treatment. Journal of Applied Polymer Science, 1998, Vol. 70, pp. 559-566.

[47] Dweiri, R. and Sahari, J., Investigations on The Electrical Properties of Carbon-based Polypropylene Composites for Bipolar Plates in Polymer Electrolyte Membrane Fuel Cell (PEMFC), Journal of Power Sources. 2007, Vol. 171, pp. 424-432.

[48] Yeetsorn, R., Fowler, M.,Tzoganakis, C., Influence of Polypyrrole on Electrical Conductivity of Injection-Thermoplastic-Composite Bipolar, Proceedings of ANTEC2009, Chicago, USA, 2009.

[49] Cunningham, N., Lefèvre, M., Lebrun, G. and Dodelet, J., Measuring The Throughplane Electrical Resistivity of Bipolar Plates (Apparatus and Methods). Journal of Power Sources, 2005, Vol. 143, pp. 93-102.

[50] Li, X. and Sabir, I., Review of Bipolar Plates in PEM Fuel Cells: Flow-field Designs. International Journal of Hydrogen Energy, 2005, Vol.30, pp. 359-371.

[51] Baurens, P. and Crouvezier, J.P.P., Innovative Concepts for Bipolar Plates. CLEFS CEA, 2005. winter(50/51), pp. 2004-2005.

[52] Muller, A., Kauranen, P., Ganski, A., and Hell, B., Injection Moulding of Graphite Composite Bipolar Plates. Journal of Power Sources, 2006, Vol. 154, pp. 467-471.

[53] Huang, J. and Baird, D.G., Compression Molding of Highly Conductive Fuel Cell Bipolar Plates from A Thermoplastic Composite. Proceedings of ANTEC2003, 2003, pp. 2151-2155.

[54] Huang, J., Baird, D.G., and McGrath, J.E., Development of Fuel Cell Bipolar Plates from Graphite Filled wet-lay Thermoplastic Composite Materials. Journal of Power Sources, 2005, Vol. 150, pp. 110-119.

[55] Kuo, J.K. and Chen, C.K., A novel Nylon-6-S316L Fiber Compound Material for Injection Molded PEM Fuel Cell Bipolar Plates. Journal of Power Sources, 2006, Vol. 162, pp. 207-214.

[56] Hsiao, M.C., Liao, S.H., Yen, M.Y., Ma, C-C.M., Lee,S-J., Chen,Y-H., Hung, C.H., Lin, Y.-F., and Xie,X-F., Electrical and Thermal Conductivities of Novel Metal Mesh Hybrid Polymer Composite Bipolar Plates for Proton Exchange Membrane Fuel Cells, Journal of Power Sources, 2010, Vol. 195, No. 2, pp. 509-515.

[57] Middelman,E., Kout,W., Vogelaar,B., Lenssen,J., Wa, E. Bipolar plates for PEM fuel cells. Journal of Power Sources, 2003.118: p. 44-46.

[58] Lee, M.-S., Chen, L.-J., He,Z.-R., Yang,S.-H., The Development of A Heterogeneous Composite Bipolar Plate of A Proton Exchange Membrane Fuel Cell. Journal of Fuel Cell Science and Technology, 2005, Vol.2, pp. 14-19. 
[59] Lutz, W., Herrmann,J., Kockelmann, M., Hosseini, H.S., Jäckel, A., Schmauder,S., Predak,S., and Busse, G., Damage Development in Short-fiber Reinforced Injection Molded Composites. Computational Materials Science, 2009, Vol. 45, pp. 698-708.

[60] Chandra, A., Kramschuster, A.J., Hu,X., Turng, L.S., Effect of Injection Molding Parameters on The Electrical Conductivity of Polycarbonate/carbon nanotube Nanocomposites. Proceedings of ANTEC2007, 2007.

[61] Yang,T., Shi,P. Study on the mesocarbon microbeads/polyphenylene sulfide composite bipolar plates applied for proton exchange membrane fuel cells. Journal of Power Sources, 2008, Vol. 175, pp 390-396.

[62] Keith,J. M., King,J. A., Barton R. L. Electrical Conductivity Modeling of Carbon-Filled Liquid-Crystalline Polymer Composites. Journal of Applied Polymer Science, 2006, Vol. 102, pp 3293-3300. 


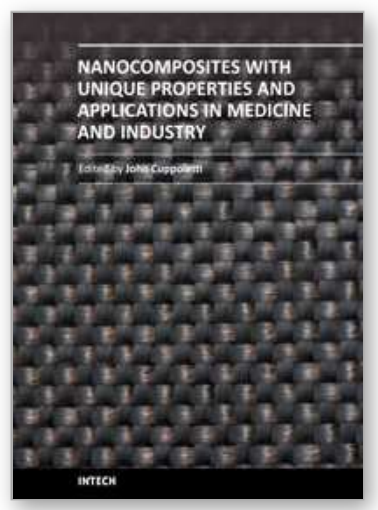

\section{Nanocomposites with Unique Properties and Applications in Medicine and Industry}

Edited by Dr. John Cuppoletti

ISBN 978-953-307-351-4

Hard cover, 360 pages

Publisher InTech

Published online 23, August, 2011

Published in print edition August, 2011

This book contains chapters on nanocomposites for engineering hard materials for high performance aircraft, rocket and automobile use, using laser pulses to form metal coatings on glass and quartz, and also tungsten carbide-cobalt nanoparticles using high voltage discharges. A major section of this book is largely devoted to chapters outlining and applying analytic methods needed for studies of nanocomposites. As such, this book will serve as good resource for such analytic methods.

\section{How to reference}

In order to correctly reference this scholarly work, feel free to copy and paste the following:

Rungsima Yeetsorn, Michael W. Fowler and Costas Tzoganakis (2011). A Review of Thermoplastic Composites for Bipolar Plate Materials in PEM Fuel Cells, Nanocomposites with Unique Properties and Applications in Medicine and Industry, Dr. John Cuppoletti (Ed.), ISBN: 978-953-307-351-4, InTech, Available from: http://www.intechopen.com/books/nanocomposites-with-unique-properties-and-applications-in-medicineand-industry/a-review-of-thermoplastic-composites-for-bipolar-plate-materials-in-pem-fuel-cells

\section{INTECH}

open science | open minds

\section{InTech Europe}

University Campus STeP Ri

Slavka Krautzeka 83/A

51000 Rijeka, Croatia

Phone: +385 (51) 770447

Fax: +385 (51) 686166

www.intechopen.com

\section{InTech China}

Unit 405, Office Block, Hotel Equatorial Shanghai

No.65, Yan An Road (West), Shanghai, 200040, China

中国上海市延安西路65号上海国际贵都大饭店办公楼 405 单元

Phone: +86-21-62489820

Fax: $+86-21-62489821$ 
(C) 2011 The Author(s). Licensee IntechOpen. This chapter is distributed under the terms of the Creative Commons Attribution-NonCommercialShareAlike-3.0 License, which permits use, distribution and reproduction for non-commercial purposes, provided the original is properly cited and derivative works building on this content are distributed under the same license. 